\title{
REVITALISASI GALERI INVESTASI DAN OPTIMALISASI \\ KSPM SEBAGAI DAYA DUKUNG PENYEDIAAN SDM YANG \\ HANDAL DI BIDANG PASAR MODAL SYARIAH
}

Fajar Adhitya

UIN Walisongo Semarang

Email: fajar.adhitya@gmail.com

\begin{abstract}
Indonesia with the $5^{\text {th }}$ most population in the world that the majority of Muslims make its own market for sharia stock investment products. The increase in sharia capital market development is not in line with the number of syariah capital market experts. For that needed buman resource development a long solution with adequate infrastructure. To overcome these limitations, strategic steps are needed such as: Kelompok Studi Pasar Modal (KSPM) Implementing the curriculum of Syariah Capital Market Learning, Galeri Investasi facilitates the implementation of Event and Intelligent Competition, Galeri Investasi and KSPM Together Facilitate Continuous opening account, KSMP Goes To Madrasah Aliyah, Regular Discussion / Sharia Capital Market Discussion, Training through Sharia Capital Market School, Implementation of certification exam training in cooperation with certification institute of Sharia Capital Market Expert (ASPM) certification training.
\end{abstract}

Keywords: Galeri Investasi, KSPM, Sharia Capital Market

\begin{abstract}
Abstrak
Indonesia dengan penduduk terpadat ke 5 di dunia yang mayoritas beragama Islam menjadikan pasar tersendiri untuk produk investasi saham syariah. Peningkatan perkembangan pasar modal syariah tidak sejalan dengan jumlah ahli syariah pasar modal. Untuk itu diperlukan solusi pengembangan sumber daya manusia disertai infrastruktur yang memadai.Untuk mengatasi keterbatasan tersebut diperlukan langkahlangkah strategis seperti: Kelompok Studi Pasar Modal (KSPM) Melaksanakan penyusunan kurikulum Pembelajaran Pasar Modal Syariah, Galeri Investasi memfasilitasi pelaksanaan Event dan Lomba Cerdas Cermat,Galeri Investasi dan KSPM Bersama-sama memfasilitasi Pembukaan Akun Saham secara kontinyu, KSMP Goes To Madrasah Aliyah, 50 | Jurnal At-Taqaddum, Volume 10, Nomor 1, Juli 2018
\end{abstract}


Diskusi rutin bedah buku/ Jurnal tentang pasar modal Syariah, Pelatihan melalui Sekolah Pasar Modal Syariah, Pelaksanaan latihan ujian sertifikasi bekerjasama dengan lembaga pelatihan sertifikasi Ahli Syariah Pasar Modal (ASPM).

Keywords: Galeri Investasi, KSPM, Pasar Modal Syariah

\section{PENDAHULUAN}

\subsection{Latar Belakang}

Indonesia dengan jumlah penduduk terpadat ke 5 di dunia yang mayoritas penduduknya memeluk agama Islam menjadikan pasar tersendiri untuk produk-produk investasi, khususnya investasi saham syariah. Pasar modal syariah Indonesia terus berkembang dari waktu ke waktu. Berdasar data Otoritas Jasa Keuangan $(\mathrm{OJK})^{1}$, jumlah saham syariah per 30 April 2017 sebanyak 354 saham, meningkat 0,29 persen dibandingkan akhir tahun 2016 sebanyak 347 saham syariah. Sementara, kapitalisasi saham syariah sebesar Rp3.402,98 triliun, meningkat 9,09\% dibandingkan kapitalisasi akhir tahun 2016 yang sebesar Rp3.119,42 triliun. Mayoritas saham syariah berasal dari sektor Perdagangan, Jasa dan Investasi sebanyak 90 saham (25,42\%), sektor Properti, Real Estate \& Konstruksi sebanyak 61 saham (17,23\%), sektor Industri Dasar dan Kimia sebanyak 52 saham (14,69\%), dan sektor Infrastruktur, Utilitas dan Transportasi sebanyak 38 saham $(10,73 \%)$. Untuk industri reksa dana syariah tercatat jumlahnya mencapai sebanyak 148 buah per 30 April 2017, atau meningkat sebesar 8,82\% dibandingkan akhir 2016 yaitu 136. Sementara, Nilai Aktiva Bersih (NAB)

${ }^{1}$ OJK (Otoritas Jasa Keuangan) merupakan Lembaga negara yang dibentuk berdasarkan undang-undang nomor 21 tahun 2011 yang berfungsi menyelenggarakan system pengaturan dan pengawasan yang terintegrasi terhadap keseluruhan kegiatan di dalam sektor jasa keuangan baik di sektor perbankan,pasar modal, dan sektor jasa keuangan non bank.

Fajar Adhitya, Revitalisasi Galeri.. 
per 30 April 2017 sebesar Rp18,13 triliun atau meningkat 21,60\% dibandingkan NAB akhir 2016 sebesar Rp14,91 triliun.

Sementara outstanding sukuk korporasi per 30 April 2017 tercatat sebanyak 60 seri, meningkat 13,21\% dibandingkan dengan akhir 2016 sebanyak 53 seri sukuk. Sedangkan, dari sisi nilainya sebesar Rp14,31 triliun, meningkat 20,45\% dibandingkan akhir 2016 yang sebesar Rp11,88 triliun. Di sisi lain, outstanding Sukuk Negara per 30 April 2017 mencapai 53 seri sukuk, jumlah tersebut sama dengan posisi akhir 2016. Dari sisi nilainya, Sukuk Negara sebesar Rp485,44 triliun, meningkat 18,01\% dari akhir tahun 2016 sebesar Rp411,37 triliun. $^{2}$

Pertumbuhan dan peningkatan industri keuangan syariah Indonesia seperti pada data di atas tidak diikuti dengan bertambahnya ahli syariah pasar modal. Berdasarkan data dari Otoritas Jasa Keuangan (OJK) pada minggu kedua bulan Juni 2018 jumlah Ahli Syariah Pasar Modal sebanyak 77 sedangkan berdasarkan Keputusan Dewan Komisioner OJK Nomor KEP-24/D.04/2018 tentang Daftar Efek Syariah bahwa jumlah perusahaan yang masuk Daftar Efek Syariah sebanyak 381 perusahaan. Daftar Efek Syariah (DES) adalah kumpulan Efek yang tidak bertentangan dengan Prinsip-prinsip Syariah di Pasar Modal, yang ditetapkan oleh Bapepam-LK atau Pihak yang disetujui Bapepam-LK. DES tersebut merupakan panduan investasi bagi Reksa Dana Syariah dalam menempatkan dana kelolaannya serta juga dapat dipergunakan oleh investor yang mempunyai keinginan untuk berinvestasi pada portofolio Efek Syariah ${ }^{3}$. Ukuran ideal untuk satu perusahaan yang terdaftar di Daftar Efek Syariah

\footnotetext{
2 Yogi Respati, "Data Perkembangan Pasar Modal Syariah Per April 2017”, http:/ / akucintakenangansyariah.com/data-perkembangan-pasar-modal-syariah-per-april-2017/, diakses pada tanggal 26 Mei 2018 pukul 09.54.

${ }^{3}$ Ojk.go.id (diakses pada 20 Juli 2018)
} 
minimal adalah satu ASPM itu artinya masih terdapat kekurangan ASPM sejumlah 304 Ahli Syariah Pasar Modal (ASPM).

Pada dasarnya pasar modal syariah dimunculkan dan dikembangkan untuk memenuhi kebutuhan umat muslim Indonesia yang memiliki minat atau memiliki keinginan untuk berinvestasi pada produk pasar modal dengan prinsip syariah. Melalui berbagai keragaman sarana dan produk investasi di Indonesia, maka masyarakat dapat memiliki alternatif berinvestasi sesuai dengan yang dikehendaki.

Investasi pada hakekatnya merupakan penempatan sejumlah dana pada saat ini dengan harapan untuk memperoleh keuntungan di masa yang akan datang ${ }^{4}$. Secara umum investasi berarti penundaan konsumsi saat ini untuk konsumsi di masa yang akan datang. Dengan demikian investasi dapat diartikan sebagai bentuk pengelolaan dana guna memberikan keuntungan dengan cara menempatkan dana tersebut pada alokasi yang diperkirakan akan memberikan tambahan keuntungan (compounding) 5

Manusia diciptakan dengan kecondongan gemar terhadap harta oleh sebab itu tanpa di imbangi kesadaran spiritual manusia akan menginginkan harta yang lebih dan lebih lagi,bahkan manusia dapat melaksanakan perbuatan yang menjadi larangan Allah SWT supaya mampu memiliki harta yang diinginkan tersebut. Dengan adanya spiritualitas dalam diri umat manusia harta mampu menjadi alat menuju kemaslahatan dunia maupun akhirat. Dalam konteks ekonomi islam, investasi merupakan bentuk aktif dari ekonomi Syariah sebab setiap harta ada zakatnya jika harta tersebut didiamkan lambat laun akan termakan oleh zakat tersebut. Salah satu manfaat dari zakat ini adalah memotivasi umat muslim menginvestasikan hartanya. Prinsip-prinsip ekonomi islam dalam investasi:

${ }^{4}$ Abdul Halim,Analisis Investasi (Salemba Empat,Jakarta,2005), hlm.4

${ }^{5}$ Irham Fahmi,Manajemen Investasi (Jakarta,Salemba Empat,2012), hlm.3

Fajar Adhitya, Revitalisasi Galeri.. 
1. Tidak mencari rizki pada hal yang haram baik zat maupun perolehannya

2. Tidak mendzalimi dan tidak didzalimi

3. Keadilan pendistribusian kemakmuran

4. Transaksi didasarkan atas dasar ridha sama ridha

5. Tidak terdapat unsur Riba, Maysir dan gharar

Kegiatan pasar modal harus disesuaikan dengan prinsip Syariah. Perputaran modal pada kegiatan pasar modal Syariah tidak boleh disalurkan kepada industri yang kegiatan operasionalnya diharamkan menurut syariat islam. Secara tidak langsung, bentuk investasi pasar modal syariah merupakan implementasi dari perintah Allah swt yang ditujukan pada manusia untuk memenuhi kesejahteraannya di dunia. Seperti yang telah difirmankan oleh Allah dalam kitab-Nya dan hadist yang disampaikan oleh Rasulullah saw antara lain:

\section{- Al Qur'an}

\section{Surat Al-Baqarah ayat 272}

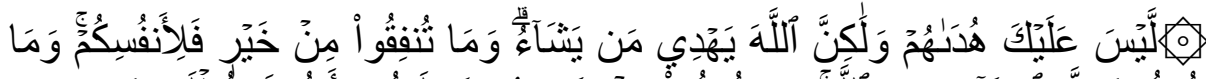

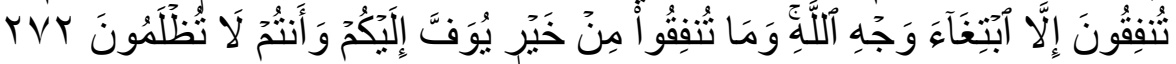
Artinya: "Bukanlah kewwajibanmu menjadikan mereka mendapat petunjuk, akan tetapi Allah-lah yang memberipetunjuk (memberi taufiq) siapa yang dikehendakiNya. Dan apa saja barta yang baik yang kamu nafkabkan (di jalan allab), maka pabalanya itu untuk. kamu sendiri. Dan janganlah kamu membelanjakan sesuatu melainkan karena mencari keridhaan Allah. Dan apa saja harta yang baik. yang kamu nafkabkan, niscaya kamu akan diberi pabalanya"

Al-Qur'an telah memberikan kita contoh nyata sebuah investasi melalui infaq di mana bila seluruh masyarakat muslim banyak melakukan infaq, maka akan dapat menolong ribuan orang miskin dan mendorong mereka untuk membuka usaha dan memberantas kemiskinan itu sendiri.maksud nya jika infaq orang-orang kaya diinvestasikan kemudian disalurkan kepada yang berhak menerima maka akan memberikan nilai untuk dunia dan akhirat. 


\section{Surat An-Nisa' ayat 9}

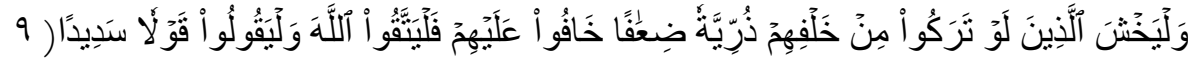

Artinya : "Dan hendaklah takut kepada Allah orang-orang yang seandainya meninggalkan di belakang mereka anak-anak yang lemah, yang mereka khawatir terhadap (kesejabteraan) mereka. Oleh sebab itu hendaklah mereka bertakwa kepada Allah dan hendaklab mereka mengucapkan perkataan yang jujur."

\section{Surat An-Nisa' ayat 29}

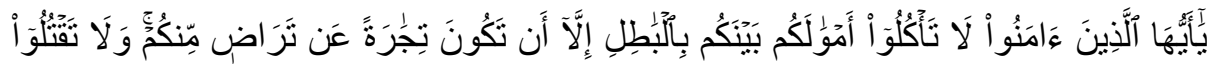

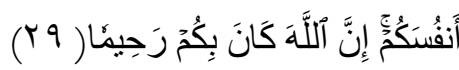

Artinya : Hai orang-orang yang beriman, janganlah kami saling memakan harta sesamamu dengan jalan yang batil, kecuali dengan jalan perniagaan yang berlaku dengan suka sama-suka di antara kamu. Dan janganlah kamu membunuh dirimu ; sesungguhnya Allah adalah Maba Penyayang kepadamu."

\section{Surat Yusuf ayat 46-50}

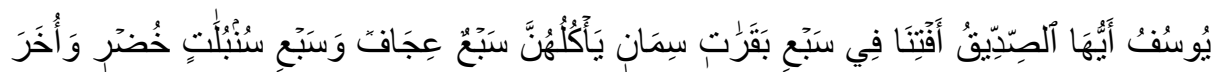

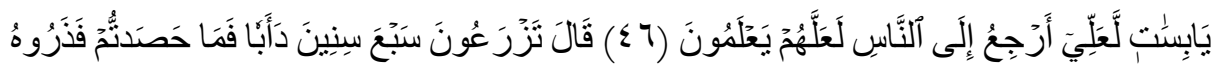

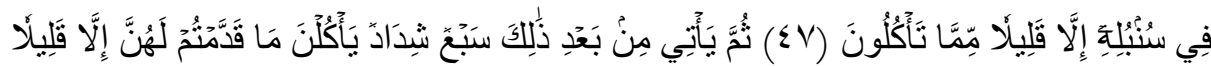

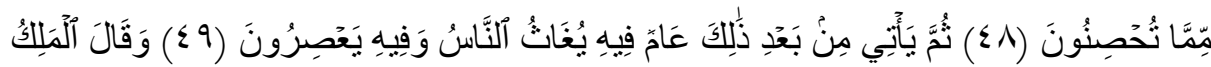

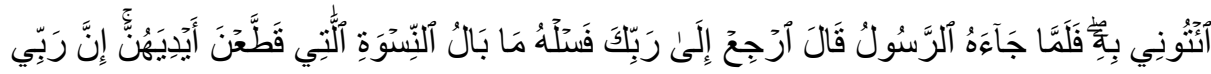

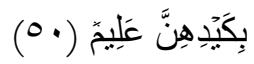

Artinya:

46. (Setelah pelayan itu berjumpa dengan Yusuf dia berseru): "Yusuf, hai orangyang amat dipercaya, terangkanlah kepada kami tentang tujuh ekor sapi betina yang gemuk-gemuk yang dimakan oleh tujuh ekor sapi betina yang kurus-kurus dan tujuh bulir (gandum) yang bijau dan (tujuh) lainnya yang kering agar aku kembali kepada orang-orang itu, agar mereka mengetabuiny a"

47. Yusuf berkata: "Supaya kamu bertanam tujuh tabun (lamanya) sebagaimana biasa; maka apa yang kamu tuai hendaklah kamu biarkan dibulirnya kecuali sedikit untuk kamu makan 
48. Kemudian sesudah itu akan datang tujub tahun yang amat sulit, yang menghabiskan apa yang kamu simpan untuk. menghadapinya (tahun sulit), kecuali sedikit dari (bibit gandum) yang kamu simpan

49. Kemudian setelah itu akan datang tabun yang padanya manusia diberi hujan (dengan cukup) dan dimasa itu mereka memeras anggur"

50. Raja berkata: "Bawalah dia kepadaku". Maka tatkala utusan itu datang kepada Yusuf, berkatalah Yusuf: "Kembalilah kepada tuanmu dan tanyakanlah kepadanya bagaimana balnya wanita-wanita yang telah melukai tangannya. Sesunggubnya Tubanku, Maba Mengetahui tipu daya mereka"

Ayat ini mengajarkan kepada kita untuk tidak mengkonsumsi semua kekayaan yang kita miliki pada saat kita telah mendapatkannya, tetapi hendaknya sebagian kekayaaan yang kita dapatkan itu juga kita tangguhkan pemanfaatannya untuk keperluan yang lebih penting. Dengan bahasa lain, ayat ini mengajarkan kepada kita untuk mengelola dan mengembangkan kekayaan demi untuk mempersiapkan masa depan. Masa depan itu bisa berarti 1,5 atau 10 tahun ke depan bahkan lebih, termasuk juga masa pensiun atau hari tua. ${ }^{6}$

\section{- Hadist}

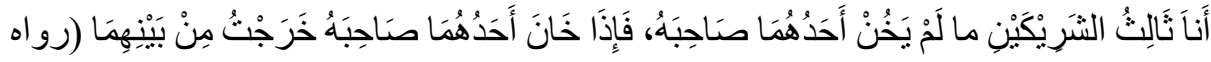

$$
\text { أبو داود عن أبي هريرة) }
$$

Artinya: "Aku (Allah) adalah yang ketiga dari dua pibak yang berserikat selama salah satu pibak tidak mengkbianati pibak yang lain. Apabila salah satu pibak telah berkbianat, Aku keluar dari mereka." Hadis Nabi riwayat Abu Dawnd dari Abu Hurairah.

'Sofwan Jauhari, 'Investasi Dalam Pandangan Al-Qur'an \& Sunnab",http:// wmw.stiualhikmah.ac.id/index.php/kecerdasan-finansial/188-investasi-dalampandangan-al-qur-an-sunnah, pada tanggal 03 Februari 2018 pukul 06.00.

${ }^{7}$ Al-Qur'an, 2:272; 3: 9; 3:29; 12:46-50; 


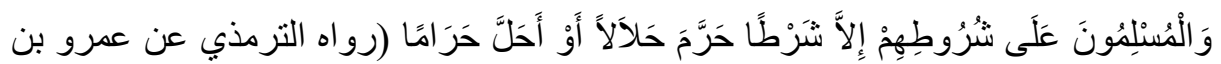

عوف)

Artinya: "Kaum muslimin terikat dengan syarat-syarat yang mereka buat kecuali syarat yang mengharamkan yang halal atau menghalalkan yang haram."Hadis Nabi riwayat al-Tirmidzi dari' Amr bin 'Auf.

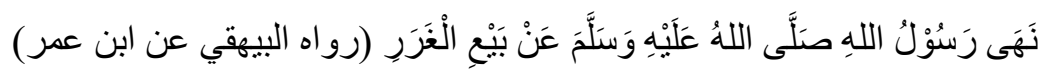

Artinya: "Rasulullah SAW melarang jual beli (yang mengandung) gharar" (HR. alBaibaqi dari Ibnu Umar)

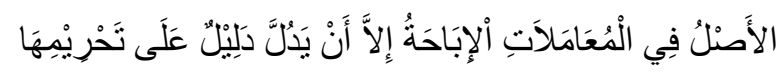

Artinya: "Pada dasarnya, segala sesuatu dalam muamalah boleh dilakukan sampai ada dalil yang mengharamkannya."

Dalam upaya merealisasikan hal di atas, maka wajarlah apabila harus disediakan dan dikembangkan SDM yang handal di bidang pasar modal yang tentunya tidak bertentangan dengan prinsip syariah. Langkah tersebut sebagai perwujudan menjadikan pasar modal syariah di Indonesia dapat berkembang dengan pesat.

\section{KAJIAN PUSTAKA}

\subsection{Konsep Pasar Modal Syariah}

Pasar modal didefinisikan sebagai pasar untuk instrumen keuangan (atau sekuritas) jangka panjang yang bisa diperjualbelikan, baik dalam bentuk hutang ataupun modal sendiri, baik yang diterbitkan oleh pemerintah, public authorities, maupun perusahaan swasta. ${ }^{8}$ Menurut Sunariyah, pasar modal secara umum adalah suatu sistem keuangan yang terorganisasi, termasuk didalamnya adalah bank-bank komersial dan semua lembaga perantara di bidang keuangan, serta keseluruhan surat-surat

\footnotetext{
${ }^{8}$ Husnan, Suad. Dasar-Dasar Teori Portofolio dan Analisis Sekuritas. (Edisi 5).
} (Yogyakarta, UPPN STIM YKPN,2015)

Fajar Adhitya, Revitalisasi Galeri.. 
berharga yang beredar'. Pasar modal merupakan tempat berbagi instrument keuangan jangka panjang yang bisa diperjualbelikan, baik surat utang (obligasi), ekuiti (saham), reksadana, instrument derivatif maupun instrument lainnya. Pasar modal merupakan wahana pendanaan bagi perusahaan maupun institusi lain (misalnya pemerintah), dan juga sebagai sarana kegiatan berinvestasi, dengan demikian pasar modal menfasilitasi berbagai sarana dan prasarana kegiatan jual beli dan kegiatan terkait lainnya. ${ }^{10}$

Secara luas, pasar modal syariah ialah suatu tempat bertemunya antara permintaan dan penawaran atas instrumen keuangan jangka panjang, yang umumnya lebih dari satu tahun. ${ }^{11}$ Pasar modal merupakan sarana pendanaan bagi perusahaan maupun institusi lainnya dan sarana bagi kegiatan berinvestasi. ${ }^{12}$

Sedangkan menurut UU no. 8 tahun 1995 tentang pasar modal menyebutkan bahwa pasar modal adalah kegiatan yang berhubungan dengan penawaran umum dan perdagangan efek yang diterbitkannya, serta lembaga dan profesi berkaitan dengan efek, sedangkan menurut fatwa Nomor 40/DSN-MUI/X/2003, pengertian efek syariah adalah efek sebagaimana dimaksud dalam peraturan perundang-undangan di bidang pasar modal yang akad, pengelolaan perusahaan, maupun cara penerbitannya memenuhi prinsip-prinsip syariah.

${ }^{9}$ Sunariyah, Pengantar Pengetahuan Pasar Modal, (Yogyakarta: UPP Akademi Manajemen Perusahaan YKPN, 2000), hlm. 4

${ }^{10}$ Martalena dan Maya Malinda, 2011, Pengantar Pasar Modal (Yogyakarta, Andi, 2011) hlm.2

${ }^{11}$ Muhammad, Samsul, "Pasar Modal dan Manajemen Portofolio”, Jakarta: Erlangga, 2006)

${ }^{12}$ Darmadji, T dan Fakhruddin, H. M., “Pasar Modal di Indonesia (Edisi 2”).(Jakarta: Salemba Empat, 2006) 
Dalam kamus istilah pasar modal dan keuangan kata investasi diartikan sebagai penanaman uang atau modal dalam suatu perusahaan untuk tujuan memperoleh keuntunga. ${ }^{13}$ Pasar modal syariah adalah pasar modal yang dijalankan dengan prinsip syariah, setiap transaksi surat berharga di pasar moda dilaksanakan sesuai dengan ketentuan syriat Islam. ${ }^{14}$

Hingga tahun 1970 sebagian besar masyarakat muslim tidak dapat terlibat dalam investasi di pasar modal. Ini dikarenakan larangan Islam pada aktivitas bisnis tertentu. Maka dari hal ini sejumlah bursa efek dunia telah disusun indeks yang secara khusus terdiri dari komponen saham saham yang tergolong kegiatan usahanya tidak melanggar prinsip syariah. ${ }^{15}$ Kegiatan pasar modal syariah di Indonesia di atur dalam UU no. 8 tahun 1995 (UUPM). Pasal 1 ayat 13 UU no. 8 tahun 95 tentang pasar modal, yakni kegiatan yang bersangkutan dengan penawaran umum dan perdagangan efek, perusahaan publik yang berkaitan degnan efek yang diterbitkannya, serta lembaga dan profesi yang berkaitan dengan efek, sedangkan efek dalam UUPM pasal 1 butir 5 dinyatakan sebagai surat berharga, yakni surat pengakuan utang, surat berharga komersial, saham obligasi, tanda bukti utang, unit penyertaan kontrak investasi kolektif, kontrak kegiatan berjangka atas efek, dan setiap derivatif efek. ${ }^{16}$

${ }^{13}$ Nurul huda,Investasi pada Pasar Modal Syariah Jakarta: Prenada Media Group, 2007), hlm.7.

${ }^{14}$ Adrian Sutedi, Pasar Modal Syariah Sarana Investasi Kenangan Berdasarkan Prinsip Syariah (Jakarta: Sinar Grafika, 2011), hlm. 29.

${ }^{15}$ Nurul huda,Investasi pada Pasar Modal Syariah (Jakarta: Prenada Media Group, 2007), hlm. 45.

${ }^{16}$ Nurul huda,Investasi pada Pasar Modal Syariah (Jakarta: Prenada Media Group, 2007), hlm. 55

Fajar Adhitya, Revitalisasi Galeri.. 
Di sini UUPM belum membedakan antara kegiatan pasar modal syaariah dan konvensiaonal. Hanya saja ruang lingkup usaha emiten yang bertentangan dengan prinsip syariah Islam adalah: ${ }^{17}$

1. Usaha perjudian dan permainan yang tergolong judi atau perdagangan yang dilarang.

2. Usaha lembaga keuangan konvensional (ribawi) termasuk perbankan dan asuransi konvensional.

3. Usaha yang memproduksi, distribusi dan memperdagangkan makanan minuman yang haram.

4. Menyediakan, memproduksi, serta mendistribusi barang-barang atau jasa ayng dapat merusak moral dan menyebabkan mudharat.

\subsection{Instrumen Pasar Modal}

\section{Saham syariah}

Saham adalah salah satu instrument pasar modal yang amat banyak digemari oleh investor, penyebabnya karena mampu memberikan tingkat pengembalian/ return yang menarik. Saham adalah kertas yang tercantum dengan jelas nilai nominal, nama perusahaan, dan diikuti dengan hak dan kewajiban yang telah dijelaskan kepada setiap pemegangnya ${ }^{18}$. Saham merupakan surat berharga yang bersifat kepemilikan atas modal pada suatu perusahaan terbatas. Dengan demikian si pemilik saham merupakan pemilik perusahaan. Semakin banyak saham yang dimiliki pada suatu perusahaan maka semakin besar power di perusahaan tersebut. Saham secara umum berbeda pengertiannya dengan saham Syariah. Pengertian Saham Syariah ialah suatu bentuk kegiatan investasi yang berupa penyertaan modal ke

${ }^{17}$ Nurul huda,Investasi pada Pasar Modal Syariah (Jakarta: Prenada Media Group, 2007), hlm. 56

${ }^{18}$ Fahmi, Irham, Pengantar Pasar Modal. (Bandung, Alfabeta.2012), hlm.81 
dalam suatu perusahaan tertentu yang mana perusahaan tersebut tidak memiliki kegiatan atau aktifitas bisnis yang melanggar prinsip Syariah. ${ }^{19}$ Keuntungan yang didapatkan dari berinvestasi saham dikenal dengan istilah deviden $^{20}$. Pembagian deviden ditentukan dan ditetapkan dalam penutupan laporan keuangan berdasarkan Rapat Umum Pemegang Saham (RUPS) ditentukan berapa deviden yang dibagi dan laba ditahan.

\section{Obligasi Syariah (sukuk)}

Obligasi atau bonds secara konvensional merupakan bukti utang dari emiten yang dijamin oleh penanggung yang mengandung janji pembayaran bunga atau janji lainnya serta pelunasan pokok pinjaman yang dilakukan pada tanggal jatuh tempo. Disini obligasi merupakan instrumen utang bagi perusahaan yang hendak memperoleh modal.

Sedangkan obligasi syariah (sukuk) adalah sesuai dengan Fatwa DSNMUI No. 32/DSN-MUI/IX/2002 adalah suatu surat berharga jangka panjang berdasarkan prinsip syariah yang dikeluarkan emiten kepada pemegang obligasi syariah yang mewajibkan emiten untuk membayar pendapatan kepada pemegang obligasi pada bagi hasil/ margin/ fee,serta membayar kembali dana obligasi pada saat jatuh tempo. Ditinjau dari segi jenis akadnya, obligasi syariah terbagi pada obligasi syariah mudharabah, jarah, musyarakah, Murabahah, Salam, Istisnha'. Di samping itu, ada juga obligasi syariah mudharabah konversi. Sedangkan ditinjau dari institusi yang menerbitkan obligasi syariah, maka obligasi syariah terbagi dua yaitu, obligasi korporasi (perusahaan) dan obligasi negara (SBSN).

${ }^{19}$ Heykal, M, Tuntunan dan Aplikasi Investasi Syariah .( Jakarta: Elex Media Komputindo Huda,2012)

${ }^{20}$ Deviden adalah pembagian laba kepada pemegang saham berdasarkan banyaknya saham yang dimiliki

Fajar Adhitya, Revitalisasi Galeri.. 
a. Sukuk korporasi

Merupakan jenis obligasi syariah yang diterbitkan oleh suatu perusahaan yang memenuhi prinsip syariah. Ada beberapa pihak yang terlibat dalam sukuk korporasi yaitu;

$\checkmark$ Obligator, adalah emiten yang bertanggung jawab atas pembayaran imbalan dan nilai nominal sukuk yang diterbitkan sampai dengan sukuk jatuh tempo.

$\checkmark$ Wali amanat (trustee) untuk mewakili kepentingan investor

$\checkmark$ Investor, yaitu pemegang sukuk yang memiliki hak atas imbalan, margin, dan nilai nominal sukuk sesuai partisipasi masing-masing

b. Surat Berharga Syariah Negara (SBSN)

Adalah surat berhaarga negara yang diterbitkan berdasarkan prinsip syariah, sebagai bukti atas bagian penyertaan terhadap aset SBSN, baik dalam mata uang rupiah maupun valuta asing. Pihak-pihak yang terlibat dalam SBSN adalah;

$\checkmark$ Obligor, adalah pihak yang bertanggung jawab atas pembayaran imbalan dan nilai nominal sukuk yang diterbitkan sampai dengan sukuk jatuh tempo.

$\checkmark$ Special Purpose Vebicle (SPV) adalah badan hukum yang didirikan khusus untuk menerbitkan sukuk dengan fungsi;

- Sebagai penerbit sukuk

- Menjadi counterpart pemerintah dalam transaksi pengalihan aset

- Bertindak sebagai wali amanat (trustee) untuk mewakili kepentingan investor.

$\checkmark$ Investor, adalah pemegang sukuk yang memiliki hak atas imbalan, margin, dan nilai nominal sukuk sesuai partisipasi masing-masing. 


\section{Reksa Dana Syariah}

Reksadana Syariah merupakan reksa dana yang beroperasi menurut ketentuan dan prinsip Syariah Islam, baik dalam bentuk akad antara pemodal sebagai pemilik harta (shahih al-mal/rabb al-mal) dengan manager investasi, begitu pula pengelolaan dana investasi sebagai wakil shahih al-mal dengan pengguna investasi. Disamping investasi secara mandiri atau secara langsung, Investor dapat meminta orang lain yang mampu dipercaya serta dipandang lebih memiliki kemampuan dalam mengelola investasi, sehingga timbul kebutuhan akan manager investasi yang memahami investasi secara syariah dan kebutuhan akan reksa dana syariah. Manager investasi, dengan akad wakala ${ }^{21}$, akan menjadi wakil dari investor untuk kepentingan dan atas nama investor. Sedangkan reksadana syariah akan bertindak dalam akad Mudharabah ${ }^{22}$ sebagai mudharib yang mengelola dana/harta milik bersama dari para pemilik harta. Sebagai bukti penyertaan pemilik dana akan mendapat unit penyertaan dari reksa dana syariah. Tetapi reksa dana syariah sebenarnya tidak bertindak sebagai mudharib murni karena reksa dana syariah akan menempatkan kembali dana kedalam kegiatan emiten melalui efek syariah. Dalam hal ini, reksa dana syariah berperan sebagai mudharib dan emiten berperan sebagai mudharib, oleh karena itu, hubungan ini disebut sebagi ikatan Mudharabah bertingkat.

\section{Efek Beragun Aset (EBA) Syariah}

Efek Beragun Aset (EBA) Syariah merupakan efek yang diterbitkan oleh kontrak investasi kolektif EBA syariah yang portofolionya terdiri dari

\footnotetext{
${ }^{21}$ Menurut Hashbi Ash Shiddieqy wakalah adalah penyerahan kekuasaan yang pada akad itu seseorang menunjuk orang lain sebagai penggantinya dalam bertindak

22 Bentuk kerjasama antara dua atau lebih pihak dimana pemilik modal (shabibul maal) mempercayakan sejumlah modal kepada pengelola (mudharib) dengan suatu perjanjian awal
}

Fajar Adhitya, Revitalisasi Galeri.. 
aset keuangan berupa tagihan yang tiimbul dari surat berharga komersial, tagihan yang timbul di kemudian hari, jual beli pemilikan aset fisik oleh lembaga keuangan. Efek bersifat investasi yang dijamin oleh pemerintah, sarana peningkatan investasi/arus kas serta keuangan aset keuangan setara yang sesuai dengan prinsip-prinsip syariah. ${ }^{23}$ Ketentuan- ketentuan melakukan penawaran umum EBA syariah, yaitu;

a. Mengikuti ketentuan umum pengajuan pernyataan pendaftaran, peratuaran [pernyataan pendaftaran dalam rangka penawaran umum efek bearagun aset (Aset Backed Securities) serta ketentuan tantang penawaran umum yang terkait lainnya.

b. Mencantumkan ketentuan dalam Kontrak Investasi Kolektif Efek Beragun Aset (KIK-EBA) syariah dan informasi tambahan dalam prospektus hal-hal sebagai berikut;

- Berapa aset yang menjadi portofolio EBA Syariah tidak bertentangan dengan prinsip-prinsip syariah di pasar modal

- Wakil manajer investasi yang melaksanakan pengelolaan KIK-EBA Syariah dan penanggungjawab atas pelaksanaan kegiatan kustodian pada Bank Kustodian mengerti kegiatan-kegiatan yang bertentangan dengan prinsip-prinsip syariah di pasar modal

- Kata "Syariah" pada nama EBA yang diterbitkan

- Mekanisme pembersihan portofolio dan dana EBA Syariah dari unsur-unsur yang bertentangan dengan prinsip-prinsip syariah di pasar modal

- Bahwa pengelolaan dana EBA Syariah dilarang bertentangan dengan prinsip-prinsip syariah di pasar modal

${ }^{23}$ Fatwa DSN MUI No 40/DSN-MUI/X/2002 tentang Pasar Modal dan Pedoman Umum Penerapan Prinsip Syariah di Pasar Modal 
- Akad syariah dan skema transaksi syariah yang digunakan dalam penerbitan efek

- Ringkasan akad syariah yang dilakukan oleh para pihak-pihak

- Besarnya nisbah pembayaran bagi hasil, margin, atau fee,

- Rencana jadwal dan tata cara pembagian dan/atau pembayarannya bagi hasil, margin, atau fee.

\section{Hak Memesan Efek Terlebih Dahulu (Right Issue)}

Fatwa DSN-MUI Nomor: 65/DSN-MUI/III/2008 tentang Hak Memesan Efek Terlebih Dahulu (HMETD) memastikan bahwa kehalalan investasi di pasar modal tidak hanya berhenti pada instrumen efek yang bernama saham saja, tetapi juga pada produk derivatifnya. Produk turunan saham (derivatif) yang dinilai sesuai dengan kriteria DSN adalah produk rights (HMETD). Produk yang bersifat hak dan melekat dengan produk induknya itu menjadi produk investasi yang sudah memenuhi kriteria DSN. Mekanisme HMETD ini dipandang lebih menguntungkan dibandingkan harus meminjam ke bank kaarena dana yang diperoleh lebih murah, tak ada biaya tambahan, provisi, dan masalah administrasibank lainnya, karena dana dipasok oleh pemegang sahamnya sendiri.

Jika pemegang saham lama tidak mau membeli tambahan saham baru tadi, dia bisa menjual sebagian atau semua rights yang dia miliki di pasar pada periode diperdagangkan. Jika memang mau menambah kepemilikannya, maka dia bisa mendapatkan saham baru pada harga Rp 950,00. Rights sebelum jatuh tempo bisa diperdagangkan. Dan hasil penjualannya rights tersebut merupakan keuntungan bagi investor yang memilikinya. 


\section{Warran Syariah}

Mekanisme warran bersifat opsional dimana warran merupakan hak untuk membeli sebuah saham pada harga yang telah ditetapkan dengan waktu yang telah ditetapkan pula. Warran sebelum jatuh tempo bisa diperdagangkan, dan hasil penjualannya warran tersebut merupakan keuntungan bagi investor yang memilikinya. Fatwa DSN-MUI Nomor: 66/DSN-MUI/III/2008 tentang Warran Syariah pada tanggal 6 maret 2008 memastikan bahwa kehalalan investasi di pasar modal tidak hanya berhenti pada instrumen efek yang bernama saham saja, tetapi juga pada produk derivatifnya. Produk turunan saham (derivatif) yang dinilai sesuai dengan kriteria DSN adalah juga warran. Berdasarkan fatwa ppengalihan saham dengan imbalan (warran), seseorang pemegang saham diperbolehkan untuk mengalihkan kepemilikaan sahamnya kepada orang lain dengan mendpatkan imbalan. ${ }^{24}$

\subsection{KELOMPOK STUDI PASAR MODAL (KSPM)}

KSPM atau Kelompok Studi Pasar Modal merupakan suatu kelompok studi mahasiswa yang berkecimpung dalam bidang pasar modal yang berusaha meningkatkan pengetahuan dan kemampuan tentang pasar modal serta instrumen-instrumenya bagi anggota KSPM dan mahasiswa pada khususnya. KSPM dibentuk dengan tujuan utama untuk memberikan wahana kepada para mahasiswa yang tertarik dan berminat untuk mengembangkan pengetahuan di bidang pasar modal dan investasi. KSPM juga diupayakan untuk dapat menjadi wahana untuk berdiskusi dan bertukar pikiran di antara para mahasiswa dan antara mahasiswa dan dosen. Dengan

\footnotetext{
${ }^{24}$ Soemitra Andri, Bank dan Lembaga Keuangan Syariah, (Jakarta: Kencana, 2014), hlm. 150-154.
} 
adanya wahana berdiskusi dan bertukar pikiran ini suasana akademis dapat terbentuk di lingkungan kampus.

KSPM bersifat lintas prodi dalam arti mahasiswa dari setiap prodi yang ada di Fakultas dapat melibatkan diri dalam KSPM, bahkan KSPM juga terbuka bagi mahasiswa dari prodi lain di fakultas lain yang berminat di bidang pasar modal dan investasi. KSPM dibentuk sebagai sebuah kelompok studi sehingga pada awalnya organisasi ini sedikit berbeda dengan HMPS maupun BEM dan Senat Mahasiswa. KSPM dibentuk untuk memberikan kesempatkan kepada mahasiswa untuk mengembangkan ilmu pengetahuan di bidang pasar modal dan investasi sehingga sifat kegiatannya sangat spesifik dan terbatas. KSPM juga terbentuk sebagai sarana untuk mendukung terbentuknya Galeri Investasi, di mana kemajuan dan keberlanjutan Galeri Investasi akan sangat terdukung jika di sebuah perguruan tinggi memiliki KSPM dan bekerja sama dengan Anggota Bursa dalam hal ini adalah perusahaan sekuritas. ${ }^{25}$

\subsection{Galeri Investasi}

Galeri Investasi Bursa Efek Indonesia (BEI) adalah sarana untuk memperkenalkan Pasar Modal sejak dini kepada dunia akademisi. Galeri Investasi BEI berkonsep 3 in 1 yang merupakan kerjasama antara BEI, Perguruan Tinggi dan Perusahaan Sekuritas diharapkan tidak hanya memperkenalkan Pasar Modal dari sisi teori saja akan tetapi juga prakteknya. Kedepannya melalui Galeri Investasi BEI yang menyediakan real time information untuk belajar menganalisa aktivitas perdagangan

\footnotetext{
${ }^{25} \mathrm{https://kspm4uajy.wordpress.com/sejarah-kspm/,} \mathrm{diakses} \mathrm{pada} \mathrm{tanggal} 15$ Juni
} 2018

Fajar Adhitya, Revitalisasi Galeri.. 
saham, diharapkan dapat menjadi jembatan menuju penguasaan ilmu pengetahuanbeserta prakteknya di pasar modal. ${ }^{26}$

Galeri Investasi BEI menyediakan semua publikasi dan bahan cetakan mengenai pasar modal yang diterbitkan oleh Bursa Efek Indonesia termasuk peraturan dan Undang-Undang Pasar Modal. Informasi dan data yang ada di Galeri Investasi BEI dapat digunakan oleh civitas akademika untuk tujuan akademik, bukan untuk tujuan komersial dalam hal transaksi jual dan beli saham. Dengan adanya Galeri Investasi BEI diharapkan dapat saling memberikan manfaat bagi semua pihak sehingga penyebaran informasi pasar modal tepat sasaran serta dapat memberikan manfaat yang optimal bagi mahasiswa, praktisi ekonomi, investor, pengamat pasar modal maupun masyarakat umum di daerah dan sekitarnya baik untuk kepentingan sosialisasi dan pendidikan/edukasi pasar modal maupun untuk kepentingan ekonomis atau alternatif investasi.

Manfaat yang diperoleh bagi masing - masing pihak dalam pendirian Galeri Investasi Bursa Efek Indonesia antara lain:

1. Manfaat untuk BEI sebagai wahana sosialisasi serta edukasi di kalangan akademis supaya dapat terwujud dengan baik, sehingga diharapkan civitas akademika tidak hanya mengetahui Pasar Modal secara teori, akan tetapi dapat langsung melakukan mempraktekannya.

2. Manfaat bagi Perguruan tinggi, ada aliansi strategis dengan para pelaku Pasar Modal (BEI, AB, Data Vendor). Meningkatkan reputasi dan nilai jual perguruan tinggi.

3. Manfaat bagi Perusahaan Efek Anggota Bursa, bermanfaat sebagai media promosi dikalangan mahasiswa/akademisi dan sebagai media rekrutmen SDM Pasar Modal yang mumpuni.

${ }^{26 I d x, ~ " G a l e r i ~ I n v e s t a s i ~ B E I ", ~ h t t p: / / w w w . i d x . c o . i d / ~ p a d a ~ t a n g g a l ~} 12$ Juni 2018 pukul 06.14. 
4. Bagi Data Vendor, sebagai ajang promosi produk data untuk kalangan akademisi, tidak mengeluarkan investasi hardware untuk pojok BEI \& Lab Pasar Modal dan sebagai media rekrutmen SDM Pasar Modal yang handal.

\section{Kewajiban bagi masing-masing pihak dalam pendirian Galeri}

\section{Investasi BEI}

1. Bursa Efek Indonesia, memberikan serta memberikan publikasi yang dikeluarkan oleh BEI, mendukung agenda/kegiatan yang berhubungan dengan sosialisasi dan edukasi Pasar Modal, menyediakan kesempatan untuk magang, memfasilitasi terbentuknya kelompok studi investasi.

2. Bagi Perguruan Tinggi, menyediakan space sekaligus infrastuktur pendukung untuk kebutuhan galeri Pojok BEI dan Lab Pasar Modal. Menyediakan PC sesuai dengan kebutuhan minimal 3 PC (2 PC untuk Data Realtime, 1 PC untuk operasional Pojok BEI) dengan pengaturan system yang layak pakai.

3. Bagi Perusahaan Efek, memberikan jasa layanan edukasi sekaligus sosialisasi Pasar Modal, sharing profit sesuai dengan perjanjian, menyediakan kesempatan magang.

4. Vendor Data realtime, memberikan fasilitas berlangganan gratis minimal 1 terminal untuk Pojok BEI sebagai Lab Pasar Modal. Melakukan layanan edukasi untuk perguruan tinggi, sekaligus sosialisasi penggunaan produk data realtime. Menyediakan tempat magang ${ }^{27}$.

${ }^{27} \mathrm{Idx}$, “Galeri Investasi BEI”, http://www.idx.co.id/id id/beranda/tentangbei/programbei/galeriinvestasibei.aspx, pada tanggal 12 Mei 2018 pukul 06.14 .

Fajar Adhitya, Revitalisasi Galeri.. 


\subsection{Ahli Syariah Pasar Modal}

Bahwa menurut Peraturan Otoritas Jasa Keuangan Nomor 19/POJK.04/2015 Tentang Penerbitan Dan Persyaratan Reksa Dana Syariah. Ahli Syariah Pasar Modal yang selanjutnya disingkat ASPM adalah $: 28$

a. orang perseorangan yang memiliki pengetahuan dan pengalaman di bidang syariah; atau

b. badan usaha yang pengurus dan pegawainya memiliki pengetahuan dan pengalaman di bidang syariah, yang memberikan nasihat dan/atau mengawasi pelaksanaan penerapan Prinsip Syariah di Pasar Modal dalam kegiatan usaha perusahaan dan/atau memberikan pernyataan kesesuaian syariah atas produk atau jasa syariah di Pasar Modal.

Kriteria SDM Pasar Modal Syariah menurut Peraturan Otoritas Jasa Keuangan Nomor 16/POJK.04/2015 tentang Ahli Syariah Pasar Modal tertera pada Bab II Pasal 3 mengenai perizinan dan persyaratan ASPM. ASPM yang merupakan orang perseorangan wajib memenuhi persyaratan sebagai berikut: ${ }^{29}$

1. Integritas, mencakup:

cakap melakukan perbuatan hukum;memiliki akhlak dan moral yang baik;tidak pernah melakukan perbuatan tercela dan/atau dihukum karena terbukti melakukan tindak pidana di bidang keuangan;tidak pernah dikenakan sanksi dalam menjalankan Kegiatan Syariah di Pasar Modal

${ }^{28}$ OJK, "POJK Nomor 19/POJK.04/2015”, http://www.ojk.go.id/id/kanal/pasar-modal/regulasi/regulasi-pasar-modalsyariah/Pages/POJK-19POJK042015.aspx, pada tanggal 5 Juni 2018 pukul 08.28.

${ }^{29}$ OJK, "POJK Nomor 16/POJK.04/2015", http://www.ojk.go.id/id/kanal/syariah/regulasi/peraturan-ojk-terkaitsyariah/Pages/Peraturan-OJK-Nomor-16-POJK-04-2015-Ahli-Syariah-PasarModal.aspx, pada 19 Juni 2018 pukul 09.28. 
karena tidak sesuai dengan Prinsip Syariah di Pasar Modal, Peraturan Otoritas Jasa Keuangan ini, dan/atau peraturan perundang-undangan lainnya yang terkait dengan syariah di bidang Pasar Modal selama 3 (tiga) tahun terakhir;tidak pernah dikenakan sanksi pencabutan izin, pembatalan persetujuan, dan/atau pembatalan pendaftaran oleh Otoritas Jasa Keuangan selama 3 (tiga) tahun terakhir;dalam waktu 5 (lima) tahun terakhir tidak pernah dinyatakan pailit atau menjadi pengurus yang dinyatakan bersalah menyebabkan suatu perusahaan dinyatakan pailit;memiliki komitmen untuk mematuhi peraturan perundangundangan; memiliki komitmen terhadap pengembangan Pasar Modal syariah; danmemiliki sikap independen dalam melakukan kegiatan di bidang Pasar Modal.

2. kompetensi, mencakup:

memiliki pendidikan paling rendah strata 1 (satu) atau sederajat;memiliki pengetahuan memadai di bidang Pasar Modal, dibuktikan dengan:

a) memiliki sertifikat yang diakui oleh Otoritas Jasa Keuangan dan diterbitkan oleh lembaga pendidikan khusus di bidang Pasar Modal berdasarkan rekomendasi dari Komite Standar Keahlian;

b) memiliki izin orang perseorangan dari Otoritas Jasa Keuangan sebagai Wakil Penjamin Emisi Efek, Wakil Perantara Pedagang Efek, atau Wakil Manajer Investasi atau terdaftar di Otoritas Jasa Keuangan sebagai Profesi Penunjang Pasar Modal; atau

c) memiliki pengalaman kerja pada institusi pengawas Pasar Modal dan/atau organisasi yang diberi kewenangan oleh Undang-Undang tentang Pasar Modal untuk mengatur dan/atau mengawasi industri Pasar Modal dengan ketentuan:

1) paling sedikit 2 (dua) tahun pada posisi manajerial; atau

2) paling sedikit 5 (lima) tahun pada posisi pelaksana, 
dalam bidang tugas dan fungsi yang terkait pengaturan dan/atau pengawasan Pasar Modal. memiliki pengetahuan memadai di bidang syariah muamalah yang dibuktikan dengan sertifikat yang diterbitkan oleh lembaga yang diakui oleh Otoritas Jasa Keuangan; dan memiliki rekomendasi yang dikeluarkan oleh Dewan Syariah Nasional - Majelis Ulama Indonesia.

Otoritas Jasa Keuangan memaparkan jika ahli syariah pasar modal merupakan anggota DPS, maka cakupan tugasnya memberikan nasihat dan saran kepada direksi dan dewan komisaris perusahaan tentang hal-hal yang berhubungan dengan prinsip syariah di pasar modal, dan mengawasi implementasi penerapan prinsip Syariah. Sementara, jika ahli syariah pasar modal merupakan anggota Tim Ahli Syariah, tugas dan tanggung jawabnya meliputi menelaah pemenuhan prinsip syariah atas produk atau jasa syariah yang diterbitkan oleh perusahaan, memberikan pendapat dan memastikan Tim Ahli Syariah memberikan pernyataan kesesuaian syariah atas produk atau jasa syariah di pasar modal, serta meminta data dan informasi kepada perusahaan dalam rangka memberikan nasihat dan melakukan pengawasan pelaksanaan penerapan prinsip syariah di pasar modal. ${ }^{30}$

\section{METODE PENELITIAN}

Penelitian ini menggunakan jenis metode penelitian kualitatif. Metode penelitian kualitatif adalah metode penelitian yang berlandaskan pada filsafat postpositivisme, digunakan untuk meneliti pada kondisi obyek yang alamiah, (sebagai lawannya adalah eksperimen) dimana peneliti adalah sebagai instrumen kunci, pengambilan sampel sumber data dilakukan secara puirposive dan snowboal, teknik pengumpulan dengan trianggulasi

${ }^{30}$ www.ojk.go.id (diakses pada 20 Juli 2018) 
(gabungan), analisis data bersifat induktif/kualitatif, dan hasil penelitian kualitatif lebih menekankan makna dari pada generalisas, ${ }^{31}$ sedangkan menurut Nana, penelitian kualitatif adalah suatu penelitian yang ditujukan untuk mendeskripsikan dan menganalisis fenomena,peristiwa, aktivitas social, sikap, kepercayaan, persepsi pemikiran, orang secara individual maupun kelompok. ${ }^{32}$

Penelitian kualitatif adalah penelitian yang bermaksud untuk memahami fenomena tentang apa yang dialami oleh subjek penelitian. Dengan begitu sesuai latar belakang penelitian maka penulis memaparkan melalui cara pendekatan deskriptif. Teknik kualitatif dengan deskriptif menghasilkan data dengan mengumpulkan dan menyusun data untuk kemudian dianalisis, bentuk akhirnya tidak berbentuk statistik, namun berbentuk kata-kata dan bahasa yang tersusun secara generalisasi.Teknik penelitian ini memperhatikan konteks yang menekankan pada pemaknaan isi komunikasi dengan melihat keabsahan obyek yang sedang diteliti.

Data yang digunakan dalam penelitian ini adalah data sekunder melalui kajian pustaka. Pengumpulan data dengan kajian Pustakan didapat berdasarkan dokumen-dokumen, jurnal-jurnal ilmiah, studi pustaka dan laporan tertulis lainnya berkaitan dengan tema yang diteliti. ${ }^{33}$

${ }^{31}$ Sugiyono, "Metode Penelitian Pendidikan (Pendidikan Kuantitatif, Kualitatif dan R\&D)”. (Bandung, Alfabeta, 2013), hlm. 14.

32 Sukmadinata, “Nana,Metode Penelitian Pendidikan”, (Bandung, PPS UPI dan PT Remaja Rosdakarya,2013),hlm. 94

33Moleong, "Metodologi Penelitian Kualitatif", (Bandung: PT Remaja Rosdakarya, 2013), hlm. 6

Fajar Adhitya, Revitalisasi Galeri.. 


\section{PEMBAHASAN}

4.1 Strategi Penyediaan dan Pengembangan SDM Ahli Syariah Pasar Modal Melalui Kelompok Studi Pasar Modal (KSPM)

Menyediakan serta Meningkatkan kapasitas kemampuan bagi sumber daya manusia yang kredibel dan akuntabel di bidang pasar modal syariah tentu tidak bisa diciptakan secara instan. Diperlukan lembaga pendidikan khusus tentang pasar modal syariah dengan menjalankan program terstruktur dan sistematis. Melalui Kelompok Studi Pasar Modal (KSPM) harapannya dapat melahirkan SDM berkualitas yang memahami prinsipprinsip syariah dan mengerti konsep pasar modal. Metode pengajaran oleh KSPM sebelumnya harus sudah tersusun melalui kurikulum mengenai pasar modal syariah sehingga tercipta sistem pendidikan yang efisien dan efektif. Kurikulum disusun mengenai dasar hukum menurut Al-quran dan hadist, dasar hukum yang ditetapkan oleh OJK, MUI, serta lembaga terkait lainnya, analisis efek syariah, pengenalan produk efek syariah, dan pemaparan mengenai profesi dalam pasar modal syariah. Dengan begitu kurikulum yang telah diajarkan dapat menjadi acuan pembelajaran dan kesiapan melakukan ujian sertifikasi oleh anggota KSPM untuk dapat menjadi cikal bakal sumber daya manusia di pasar modal syariah yang berkualitas dan profesional.

4.2 Galeri Investasi memfasilitasi pelaksanaan Event dan Lomba Cerdas Cermat

Hal ini merupakan langkah awal untuk mengenalkan pasar modal syariah kepada masyarakat. Kegiatan ini dapat dilakukanoleh KSPM melalui pameran dan perkenalan produk-produk pasar modal Syariah dengan difasilitasi oleh Galeri Investasi. Dengan pembukaan stand pameran yang menarik, KSPM dapat mempromosikan tentang pasar modal syariah 
kepada masyarakat yang belum tahu tentang pasar modal syariah, tujuannya agar mereka tertarik dan mau mempelajarinya.

Kegiatan ini dapat dilakukan untuk mencari bakat seorang praktisi pasar modal syariah antara lain melalui permainan cerdas cermat mengenai pasar modal syariah. Semisal,setiap hari Kemerdekaan RI, KSPM mengadakan sebuah ajang cerdas cermat dengan memberikan materi terlebih dahulu untuk dapat dipelajari dengan sebuah brosur yang berisikan materi. Brosur tersebut harus semenarik mungkin dan tidak terlalu banyak. Cukup materi dasar seperti, pengertian dan istilah-istilah yang singkat. Dengan ini nantinya yang akan dijadikan soal langsung setelah para peserta selesai membaca brosur tersebut. Berikan pertanyaan 5 sampai 7 dengan sebagian besar yang ada dalam brosur tersebut, dan sebagian kecil pengetahuan umum di bidang pasar modal syariah.

Dengan begitu kegiatan ini akan menarik bakat yang tersembunyi dari seseorang ketika mereka berkeinginan untuk mengikuti permainan tersebut, maka mereka yang benar-benar tertarik akan mempelajarinya dengan serius dan akan mendorong untuk ikut bergabung sebagai anggota KSPM dan mengikuti tahap selanjutnya untuk dapat menjadi seorang ahli di bidang pasar modal syariah.

4.3 Galeri Investasi dan KSPM Bersama-sama memfasilitasi Pembukaan Akun Saham secara kontinyu

Dengan semakin banyaknya investor baru/ investor pemula yang melakukan pembukaan akun, maka akan meningkatkan kemampuan dari seseorang untuk menganalisis pasar saham Syariah, karena dengan melalui pembukaan akun saham yang dilakukan terus-menerus dapat menambah jumlah investor dan secara otomatis investor tersebut harus mengelola akun mereka masing-masing. Pada akhirnya mereka akan mengetahui seluk beluk 
dari pasar modal syariah dan dapat menjadi ahli di bidang pasar modal syariah.

Para investor yang terus menerus melakukan trading dan analisis lewat akun mereka masing-masing ini nantinya akan dapat mengelola dan menjadi praktisi pada akunnya sendiri. Dalam jangka waktu yang singkat mereka akan paham dan dapat menyalurkan ilmunya pada orang lain serta diharapkan dapat menjadi praktisinya pasar modal syariah.

\subsection{KSMP Goes To Madrasah Aliyah}

Dalam rangka memperkenalkan pasar modal khususnya dibidang pasar modal Syariah, diperlukan sosialisasi dini di tingkat Sekolah Menengah Atas/Aliyah. Khusus untuk pengenalan di bidang pasar modal Syariah pengenalan pasar modal Syariah difokuskan pada Madrasah Aliyah. Setelah dilakukan sosialisasi dan pembelajaran pasar modal syariah pada akhir tahun diadakan olimpiade pasar modal Syariah.

4.5 Diskusi rutin bedah buku/jurnal tentang pasar modal Syariah

Melakukan reviews buku/jurnal kemudian salah satu anggota KSPM ada yang berperan sebagai narasumber menyampaikan pada saat diskusi rutin yang diselenggarakan oleh galeri investasi. Diskusi rutin diadakan pada hari senin dan kamis setiap minggunya

\subsection{Pelatihan melalui Sekolah Pasar Modal Syariah}

Kurikulum yang tersusun tentu tidak cukup jika hanya diajarkan melalui audio visual saja, namun diperlukan tindakan nyata untuk dapat terjun langsung menjadi SDM yang profesional. Mengacu pada hal tersebut,

maka pelaksanaannya dapat dengan membentuk kegiatan khusus yang langsung pada pelatihan/praktik agar pemahaman diberikan bukan sekedar teori. 
KSPM dapat melakukan kerjasama dengan IDX untuk mengadakan sekolah pasar modal syariah. Sama halnya dengan SPMS, maka diadakan kegiatan sesuai tingkatan level, dengan demikian SPMS bisa diikuti dari tingkatan paling dasar hingga pelatihan analisa fundamental dan teknikal dengan tingkatan yang lebih tinggi.

4.7 Pelaksanaan latihan ujian sertifikasi bekerjasama dengan lembaga pelatihan sertifikasi Ahli Syariah Pasar Modal (ASPM)

Setelah 6 (enam) program kegiatan di atas sudah di laksanakan, maka langkah selanjutnya untuk menjadi ahli Syariah pasar modal adalah dengan mengikuti pelatihan dan ujian profesi di lembaga resmi seperti TICMI.

\section{PENUTUP}

\subsection{KESIMPULAN}

Upaya pemenuhan SDM di bidang pasar modal Syariah atau yang lebih dikenal sebagai Ahli Syariah Pasar Modal (ASPM) tidak dapat dilakukan secara tiba-tiba. ASPM yang tersedia baru 77 untuk memenuhi kekurangan jumlah ASPM diperlukan langkah-langkah strategis untuk menyiapkan seseorang menjadi ahli pasar modal Syariah. Langkah-langkah strategis yang dapat dilakukan yaitu: Optimalisasi lembaga pendidikan terkait melalui pembentukan Kelompok Studi Pasar Modal (KSPM) dengan penyusunan kurikulum, Mengadakan Banyak Event Menarik (Mengadakan Event Game Cerdas Cermat), Mengadakan Pembukaan Akun Saham secara kontinyu, KSMP Goes To Madrasah Aliyah, Diskusi rutin bedah buku/ Jurnal tentang pasar modal Syariah, Pelatihan melalui Sekolah Pasar Modal Syariah, Pelaksanaan latihan ujian sertifikasi bekerjasama dengan lembaga pelatihan sertifikasi Ahli Syariah Pasar Modal (ASPM). 


\subsection{SARAN}

Adapun saran yang dapat diberikan melalui penelitian ini adalah sebagai berikut :

1. Kepada pemerintah dan lembaga terkait supaya turut berkontribusi aktif baik berupa dukungan material (dana pengembangan galeri Investasi dan KSPM) maupun non materiil (pengembangan kurikulum di sekolah-sekolah) yang berfokus pada pasar modal syariah.

2. Kepada pengurus KSPM dan siswa-siswi madrasah Aliyah agar dapat mengimplementasikan langkah-langkah strategis yang telah diuraikan oleh penulis dengan maksimal.

3. Karya ilmiah ini bisa menjadikan masukan bagi penulis lain yang tertarik di bidang pasar modal syariah untuk mengembangkan ide-ide serta gagasan-gagasan yang belum dipaparkan dalam karya ilmiah ini.

\section{REFERENSI}

Ardiansyah, Hendri Nur. 2012. Pengaruh Indeks Nikkel 225 Terhadap Pergerakan IHSG di Bursa Efek Indonesia. Bandung: Universitas Pendidikan Indonesia.

A Sudrajat. 2015. repository.widyatama.ac.id. Diakses pada 04 Mei 2017

Darmadji, T dan Fakhruddin, H. M. 2006. Pasar Modal di Indonesia (Edisi 2). Jakarta: Salemba Empat.

Huda, Nurul dan Edwin Nasution. 2007. Investasi pada Pasar Modal Syariah. Jakarta: Prenada Media Group.

Husnan, Suad. (2015). Dasar-Dasar Teori Portofolio dan Analisis Sekuritas. (Edisi 5). Yogyakarta :UPPN STIM YKPN.

Heykal, M. (2012). Tuntunan dan Aplikasi Investasi Syariah . Jakarta: Elex Media Komputindo Huda

Martalena dan Maya Malinda, 2011, Pengantar Pasar Modal, ANDI, Yogyakarta. 
Moleong. 2011. Metodologi Penelitian Kualitatif. Bandung: PT Remaja Rosdakarya.

Muhammad, Samsul. Pasar Modal dan Manajemen Portofolio. Jakarta: Erlangga.

Sunariyah. Pengantar Pengetahuan Pasar Modal. Yogyakarta: UPP Akademi Manajemen Perusahaan YKPN, 2000.

Soemitra, Andri. 2014. Bank dan Lembaga Keuangan Syariah. Jakarta: Kencana

Sugiono. 2013. Metode Penelitian Pendidikan Pendidikan Kuantitatif, Kualitatif dan R\&D. Bandung: Alfabeta

Sutedi, Adrian. 2011. Pasar Modal Syariah Sarana Investasi Kenangan Berdasarkan Prinsip Syariah. Jakarta: Sinar Grafika.

http://www.ojk.go.id/id/kanal/pasar-modal/regulasi/regulasi-pasarmodal-syariah/Pages/POJK-19POJK042015.aspx. Diakses pada 19 Juli 2018.

http://www.ojk.go.id/id/kanal/syariah/regulasi/peraturan-ojk-terkaitsyariah/Pages/Peraturan-OJK-Nomor-16-POJK-04-2015-Ahli-

Syariah-Pasar-Modal.aspxDiakses tanggal 19 Juni 2018

http://sekolahpasarmodal.idx.co.id/education/sekolah-pasar-modal/.

Diakses pada 04 Mei 2018.

http://www.stiualhikmah.ac.id/index.php/kecerdasan-finansial/188investasi-dalam-pandangan-al-qur-an-sunnah. Diakses pada 03 Februari 2018.

https://kspm4uajy.wordpress.com/sejarah-kspm/. Diakses pada 04 Juli 2018.

http://www.idx.co.id/id-

id/beranda/tentangbei/programbei/galeriinvestasibei.aspx. Diakses pada 04 Juli 2018. 
http://akucintakeuangansyariah.com/data-perkembangan-pasar-modalsyariah-per-april-2017/. Diakses pada 26 Mei 2018 